\title{
R efinement of the rail-wheel contact pair to improve rail-wheel interaction conditions for railway vehicles with an increased axle load
}

\author{
Institute of Technical Mechanics \\ of the National Academy of Sciences of U kraine and the State Space Agency of U kraine \\ 15 Leshko-Popel St., D nipro 49600, U kraine; e-mail: mokriyt@ gmail.com
}

\begin{abstract}
At present, one of the global trends in railway transport development, which becomes clearer and clearer, is increasing the axle load of freight cars, which gives a considerable economic benefit. In this connection, of importance is not only the car design, but also the car capacity utilization factor: the higher this factor, the more economically efficient the car use. Because of this, one of the priority global lines in increasing the volume of fright traffic and the railway operation efficiency is increasing the carrying capacity of freight cars. Preparing the railways for cars with increased axle loads calls for the development of measures to decrease the track deformability, in particular by choosing appropriate wheel and rail profiles.

The aim of this work was to develop recommendations on refining the wheel-rail contact pair to improve curve negotiation by railway vehicles with an increased axle loads on the Ukrainian railways. This paper presents the proprietary R-ITM wear-resistant railhead profile. The effect of the new profile on wheel-rail interaction in negotiating a curve of radius $300 \mathrm{~m}$ at a constant speed was studied for different cars. In doing so, emphasis was on wheel-rail interaction for a new-generation freight car on 18-9817 trucks with an axle load increased to 36 tf.

The studies conducted made it possible to formulate the following recommendations: to improve curve negotiation by railway vehicles with increased axle loads, reduce the adverse effect on the track and improve traffic safety, new proprietary contact pair profiles are recommended: the ITM-73-03 wheel profile for cars, and the R-ITM railhead profile for outer rails together with the standard R65 railhead profile for inner rails.
\end{abstract}

Keywords railhead profile, freight car with an increased axle load, curve negotiation, rail-wheel contact pair refinement.

1. Trends in the development of present-day car building. URL: http://scbist.com/wiki/18428-tendencii-razvitiya-sovremennogovagonostroeniya.html (last accessed on August 8, 2017). (in Russian).

2. William J. H., Ebersöhn W., Lundgren J., Tournay H., Zakharov S. Guidelines to Best Practices for Heavy Haul Railway Operations : Wheel and Rail Interface Issues. USA: International Heavy Haul Association, 2001. 482 pp.

3. Boronenko Yu., Tret'yakov A., Zimakova M. Assessmant of the possibility and efficiency of increasing the axle load of freight cars. Railway Equipment. 2017. No. 1 (37). Pp. 32-37. (in Russian).

4. 18-9817 two-axle truck with a wheelset-to-rail load of $25 \mathrm{tf}$. URL: http://okb.at.ua/publ/telezhka_dvukhosnaja_modeli_18_9817_s_nagruzkoj_ot kolesnoj_pary_na_relsy_25t/1-1-0-6 (last accessed on December 23, 2016). (in Russian).

5. Ushkalov V. F., Mokrii T. F., Malysheva I. Yu., Bezrukavyi N. V. Wearresistant wheel profile for a freight car with an increased axle load. Teh. Meh. 2018. No. 1. Pp. 20-29/ (in Russian).

https://doi.org/10.15407/itm2018.01.020

6. Magel E., Tajaddini A. Rail and Wheel Profile Optimization. Zheleznye Dorogi Mira. 2007. No. 10. Pp. 62-64. (in Russian). 
7. Zakharov S., Goryacheva I., Bogdanov V., Pogorelov D., Zharov I.

Problems with wheel and rail profiles selection and optimization. Wear. 2008.

V. 265. Pp. 1266-1272.

https://doi.org/10.1016/j.wear.2008.03.026

Received on November 16, 2021

in final form on December 1, 2021 